\title{
Thyroxine Transport and Distribution in Nagase Analbuminemic Rats
}

\author{
Carl M. Mendel, ${ }^{\star}$ Ralph R. Cavalieri, ${ }^{\ddagger}$ Lawrence A. Gavin, ${ }^{*}$ Tom Pettersson, ${ }^{5}$ and Masayasu Inoue" \\ *Cardiovascular Research Institute, Liver Center, and Department of Medicine, University of California, San Francisco, California \\ 94143-0130; ${ }^{\ddagger}$ Department of Medicine, Veterans Administration Medical Center and University of California, San Francisco, \\ California 94121; \$Department of Clinical Chemistry, Karolinska Institute, S-182 88 Danderyd, Sweden; and "Department \\ of Biochemistry, Kumamoto University Medical School, 2-2-1, Honjo, Kumamoto 860, Japan
}

\begin{abstract}
The postulate that thyroxine $\left(T_{4}\right)$ in plasma enters tissues by protein-mediated transport or enhanced dissociation from plasma-binding proteins leads to the conclusion that almost all $T_{4}$ uptake by tissues in the rat occurs via the pool of albuminbound $\mathrm{T}_{4}$ (Pardridge, W. M., B. N. Premachandra, and G. Fierer. 1985. Am. J. Physiol. 248:G545-G550). To directly test this postulate, and to test more generally whether albumin might play a special role in $T_{4}$ transport in the rat, we performed in vivo kinetics studies in six Nagase analbuminemic rats and in six control rats, all of whom had similar serum $T_{4}$ concentrations and percent free $T_{4}$ values. Evaluation of the plasma disappearance curves of simultaneously injected ${ }^{125} \mathrm{I}-\mathrm{T}_{4}$ and ${ }^{131} I$-albumin indicated that the flux of $T_{4}$ from the extracellular compartment into the rapidly exchangeable intracellular compartment was similar in the analbuminemic rats $(51 \pm 21 \mathrm{ng} / \mathrm{min}$, mean $\pm \mathrm{SD})$ and in the control rats $(54 \pm 15$ $\mathrm{ng} / \mathrm{min}$ ), as was the size of the rapidly exchangeable intracellular pool of $\mathrm{T}_{4}(1.13 \pm 0.53 \mathrm{vs} .1 .22 \pm 0.36 \mu \mathrm{g})$. This latter finding was confirmed by direct analysis of tissue samples (liver, kidney, and brain). We also performed in vitro kinetics studies using the isolated perfused rat liver. The single-pass fractional extraction by normal rat liver of $T_{4}$ in pooled analbuminemic rat serum was indistinguishable from that of $T_{4}$ in pooled control rat serum $(10.9 \pm 3.3 \%, n=3$, vs. $11.4 \pm 3.4 \%)$. When $>98 \%$ of the albumin was removed from normal rat serum by chromatography with Affi-Gel blue, the single-pass fractional extraction of $\mathrm{T}_{4}$ (measured by a bolus injection method) did not change $(16.3 \pm 2.1 \%, n=5$, vs. $15.2 \pm 2.5 \%)$. These data provide the first valid experimental test of the enhanced dissociation hypothesis and indicate that there is no special, substantive role for albumin in $T_{4}$ transport in the rat.
\end{abstract}

\section{Introduction}

The mechanism whereby thyroxine $\left(\mathrm{T}_{4}\right)^{1}$ in plasma enters tissues is an area of active investigation. The evidence that it

Presented in part at the 62nd Annual Meeting of the American Thyroid Association, Washington, DC, September 1987. (Abstract 49.)

Address reprint requests to Dr. Carl M. Mendel, Cardiovascular Research Institute, University of California, San Francisco, CA 94143-0130.

Received for publication 4 May 1988 and in revised form 13 July 1988.

1. Abbreviations used in this paper: $\mathrm{FDH}$, familial dysalbuminemic hyperthyroxinemia; $\mathrm{T}_{4}$, thyroxine; TBPA, serum prealbumin.

J. Clin. Invest.

(c) The American Society for Clinical Investigation, Inc.

0021-9738/89/01/0143/06 \$2.00

Volume 83, January 1989, 143-148 enters tissues via the pool of unbound (free) hormone is indirect, but compelling. This evidence includes the observations that the rate of tissue uptake of $T_{4}$ has never been found to exceed the rate of spontaneous dissociation of $T_{4}$ from its plasma-binding proteins within the tissue vasculature (1-4). If tissue uptake of $T_{4}$ does occur exclusively via the pool of free hormone, however, the tissue uptake rate constant acting on

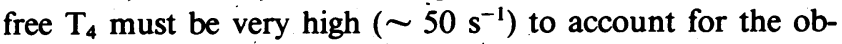
served data $(3,5)$. That is, if $10 \%$ of the $T_{4}$ in serum is taken up via the free pool by a tissue in a single transit, and if only $0.02 \%$ of the $T_{4}$ in that serum is free, the tissue uptake rate constant must be high enough to allow the pool of free $T_{4}$ to turn over 500 times during that transit. Tissue uptake rate constants this high are not measureable by currently available techniques; the highest tissue uptake rate constant presently measureable appears to be on the order of $1-3 s^{-1}$ (3). Recent documentation that the rate constant for the uptake of $T_{4}$ by rat liver is $\geq 1 \mathrm{~s}^{-1}$ (3), contradicting a previous report to the contrary (5), is therefore also consistent with the indirect evidence that tissue uptake of $\mathrm{T}_{4}$ occurs via the pool of free hormone.

Nevertheless, an alternative hypothesis regarding the mechanism of $\mathrm{T}_{4}$ uptake by tissues; the protein-mediated transport or enhanced dissociation hypothesis (5-7), has been proposed. This hypothesis assumes that spontaneous mechanisms of tissue uptake of free $T_{4}$ cannot account for the observed rates of tissue uptake of $T_{4}$ from serum, and that catalytic mechanisms that act to release $T_{4}$ from certain binding proteins (but not from others) must therefore exist within the tissue vasculature. In the rat, these mechanisms are postulated to act on albumin-bound $T_{4}$, but not on prealbumin-bound $T_{4}$, such that the observed tissue uptake of $T_{4}$ is postulated to occur almost entirely from the albumin-bound pool of $T_{4}(5)$.

Although recent studies comparing the enhanced dissociation hypothesis with the hypothesis that tissue uptake of $\mathrm{T}_{4}$ (and of other hormones) occurs spontaneously via the pool of free hormone have been interpreted as supporting the enhanced dissociation hypothesis (5-7), the results of these studies have all been analyzed with very restrictive assumptions placed on the free hormone transport model $(3,4)$. In the absence of these restrictive assumptions, which presently seem difficult to justify $(3,4)$, the data examined fit both models equally well $(3,4)$. If the two models are to be considered on an equal footing, it is very difficult to distinguish between them because in most situations both yield identical predictions. However, a special role for albumin in the uptake of $T_{4}$ by tissues, which is predicted by the enhanced dissociation hypothesis but not by the free hormone transport hypothesis, can be directly tested. In this study, we used an inbred strain of analbuminemic rats to test this postulated role of albumin.

\section{Methods}

Materials. ${ }^{125} \mathrm{I}-\mathrm{T}_{4}(1,250 \mu \mathrm{Ci} / \mu \mathrm{g})$ was purchased from New England Nuclear (Boston, MA). It was prepurified before each experiment by 


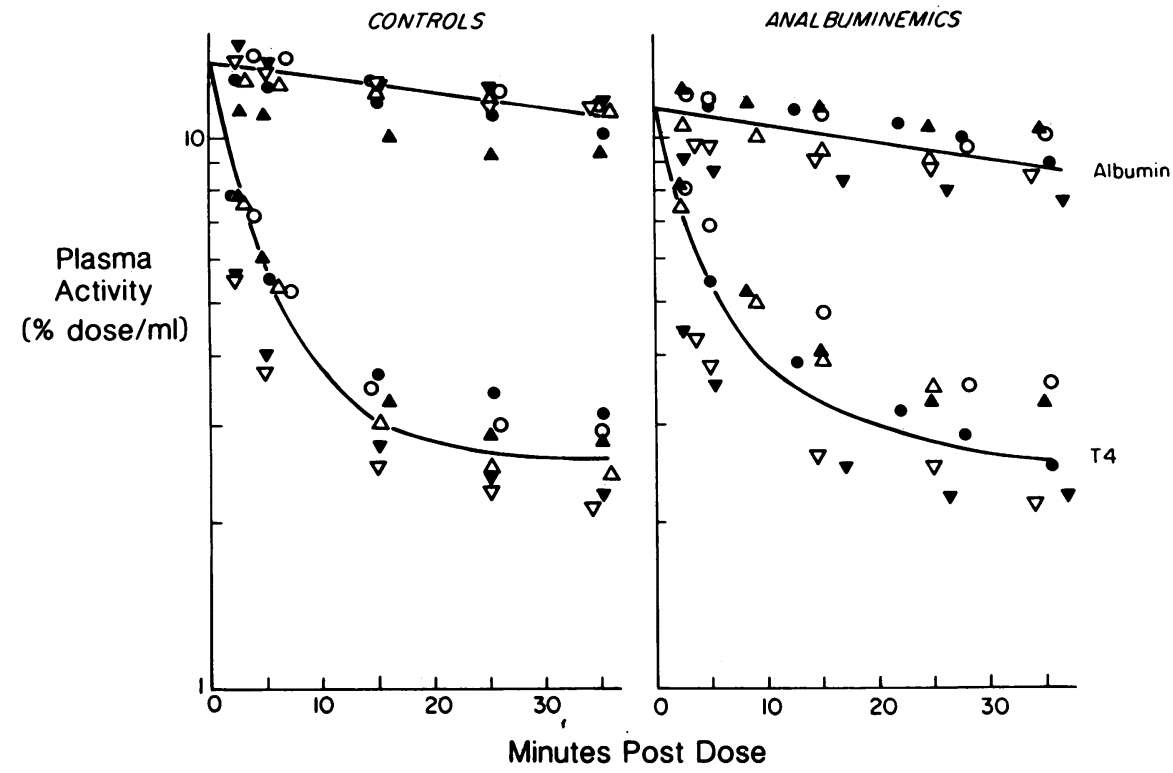

Figure 1. Plasma disappearance curves of ${ }^{125} \mathrm{I}-\mathrm{T}_{4}$ (bottom curves) and ${ }^{131} \mathrm{I}$-albumin (top curves) during the first $35 \mathrm{~min}$ after intravenous injection. Each symbol represents a single rat. The same symbol representing each rat is used for both the $T_{4}$ and the albumin data. reverse-phase chromatography using small disposable Sep-Pak C18 cartridges (Waters Associates, Milford, MA). The $T_{4}$ was applied to the column in and free iodide was eluted with a solution of methanol/ water (1:1) containing $0.3 \mathrm{ml}$ of $85 \%$ phosphoric acid/liter. The $T_{4}$ was then eluted with $100 \%$ methanol. This procedure yielded $T_{4}$ with a purity of $>99 \%$, as determined by reverse-phase HPLC (8). The purified $T_{4}$ was shielded from ultraviolet light before and during use $(9,10)$. Rabbit anti-rat albumin (IgG fraction) was purchased from Cooper Biomedicals (Malvern, PA). Human ${ }^{131} \mathrm{I}$-albumin $(10 \mu \mathrm{Ci} / \mathrm{mg})$ was purchased from Syncor (Berkeley, CA).

Animals. Retired female breeder Sprague-Dawley rats (250-350 g) were purchased from Bantin Kingman (San Leandro, CA). Retired female breeder Nagase analbuminemic rats (250-350 g), an inbred strain of Sprague-Dawley rats (11), were obtained from the colony of Dr. J. Roy Chowdhury (Albert Einstein College of Medicine, New York, NY). Older female rats were chosen for this study because their serum concentrations of total and free $T_{4}$ are identical to those of controls, whereas these concentrations differ slightly from controls in other age and sex groups of analbuminemic rats (12). The gene mutation responsible for the analbuminemia in these rats is a 7-bp deletion that occurs in an intron and results in impaired processing of the mRNA for albumin (13). Serum albumin concentrations in homozygotes are always $<0.5 \%$ of normal (13).

In vivo kinetics. In vivo kinetics studies were performed as described by Hasen et al. (14), except that radioisotopes were injected into the exposed femoral vein and blood was sampled (2-35 min after dose) from exposed tributaries of the external jugular vein. The rats were anesthetized before the experiment by intraperitoneal injection of $5 \mathrm{mg} / 100 \mathrm{~g}$ body weight sodium pentobarbital (Abbott Laboratories, Chicago, IL), and were killed after the experiment without regaining consciousness. Total blood drawing during the experiment changed the blood volume of each rat by $<10 \%$.

Human ${ }^{131} \mathrm{I}$-albumin $(1 \mu \mathrm{Ci})$ and ${ }^{125} \mathrm{I}_{-} \mathrm{T}_{4}(2 \mu \mathrm{Ci})$ were injected simultaneously in a total volume of $0.5 \mathrm{ml}$ of $5 \%$ (vol/vol) rat plasma (normal or analbuminemic, as appropriate) in $0.9 \% \mathrm{NaCl}$. Their plasma disappearance curves were analyzed by the method of Oppenheimer et al. (15), as described previously (16). Movement of $T_{4}$ into the extraalbumin space was assumed to represent movement of $T_{4}$ from the extracellular compartment into the rapidly equilibrating intracellular compartment $(14,15)$. When tissues were directly analyzed for their intracellular content of ${ }^{125} \mathrm{I}_{-} \mathrm{T}_{4}$, whole organs were minced and their radioactivity was measured. Their content of ${ }^{131} \mathrm{I}$-albumin was used to correct for extracellular ${ }^{125} \mathrm{I}-\mathrm{T}_{4}$, as described by Hasen et al. (14).
It has previously been shown that the distribution kinetics of human albumin in the rat are indistinguishable from those of rat albumin over the time course of these experiments (14). Human albumin thus should serve as a valid marker of the early distribution kinetics of plasma proteins in the normal rat. Although the plasma half-life of injected albumin is prolonged in the analbuminemic rat (13), the data presented here indicate that the early (0-35 min) distribution kinetics of albumin are normal in the analbuminemic rat. Human albumin thus should also serve as a valid marker of the early distribution kinetics of plasma proteins in the analbuminemic rat. ${ }^{2}$

Liver perfusion. In vitro single-pass liver perfusions were performed at $37^{\circ} \mathrm{C}$ in a humidified and thermoregulated cabinet as previously described $(3,10)$. The flow rate used was $1 \mathrm{ml} \cdot \mathrm{min}^{-1} \cdot \mathrm{g}$ liver ${ }^{-1}$. Sera were adjusted to $\mathrm{pH} 7.4$ by gassing with $95 \% \mathrm{O}_{2} / 5 \% \mathrm{CO}_{2}$. The hepatic extraction of $\mathrm{T}_{4}$ from serum was calculated as $\left(C_{\mathrm{in}}-C_{\mathrm{out}}\right) / C_{\mathrm{in}}$, where $C_{\mathrm{in}}$ is the concentration of ${ }^{125} \mathrm{I}-\mathrm{T}_{4}$ in the perfusate entering the liver and $C_{\text {out }}$ is its concentration in the effluent (determined at $60 \mathrm{~s}$, by which time steady state uptake had been achieved). Because efflux of radiolabeled $T_{4}$ from the liver is minimal under the experimental conditions used $(3,10)$, these measured extractions reflect initial rates of uptake. In experiments in which a bolus injection method was used, a 200- $\mu$ l bolus of test solution was injected with a syringe (Hamilton Co., Reno; $\mathrm{NV}$ ) into the tubing just before its entrance into the portal vein, with protein-free Krebs-Henseleit buffer flowing in the tubing at a rate of 1 $\mathrm{ml} \cdot \mathrm{min}^{-1} \cdot \mathrm{g}$ liver $^{-1}$. The effluent was then collected for $30 \mathrm{~s}$, and the fractional extraction was calculated from the radioactivity in the total effluent and the radioactivity in the injected bolus.

Miscellaneous. Commercial kits were used to measure serum $T_{4}$ (Ames, Elkhart, IN) and $T_{3}$ (Corning Glass Works, Medfield, MA)

2. If TBPA were to exit the early albumin distribution space in the analbuminemic rats, then our calculated rates of $T_{4}$ flux and intracellular $T_{4}$ pool size in these rats would overestimate their true values. However, this would affect our overall conclusions only if the majority of TBPA exited the albumin distribution space within $35 \mathrm{~min}$. This seems unlikely given the similarity in size and charge of albumin and TBPA (25), and seems exceedingly unlikely given the fact that nonalbumin plasma proteins in the analbuminemic rat are known not to have increased distribution volumes (26). In addition, it should be pointed out that the specific data regarding the liver that are to be presented and that support our overall kinetics data would be unaffected by such a circumstance, because of the open circulation of the liver. 


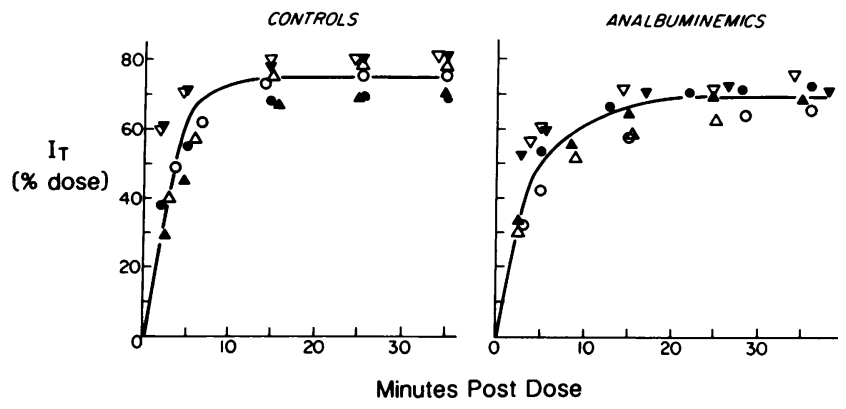

Figure 2. Time course of computed values for the ${ }^{125} \mathrm{I}_{-} \mathrm{T}_{4}$ content in the extraalbumin (i.e., intracellular) space $\left(\mathrm{I}_{\mathrm{T}}\right)$. The data are derived from the data in Fig. 1. Each rat is represented by the same symbol here as in Fig. 1.

concentrations (17). Serum-free $T_{4}$ concentrations were measured by equilibrium dialysis as previously described (17), except that $\mathrm{Ca}^{2+}$ - and $\mathrm{Mg}^{2+}$-free Dulbecco's PBS was used as the diluent buffer (1:20). Serum prealbumin (TBPA) concentrations were measured by electroimmunoassay (18). For this assay, rat TBPA was isolated by affinity chromatography using retinol-binding protein coupled to Sepharose 4B (Pharmacia Fine Chemicals, Piscataway, NJ) (19), and antibodies were raised in rabbits as previously described (19). Serum albumin concentrations were measured by immunodiffusion as previously described (20), using pooled normal rat serum as a standard and $50 \mu \mathrm{l}$ of antibody (plus $50 \mu$ l of rabbit serum) per $10 \mathrm{ml}$ of gel (1\% agarose in $0.9 \%$ $\mathrm{NaCl}, 0.05 \%$ EDTA, and $20 \mathrm{mM}$ Tris, $\mathrm{pH} \mathrm{8.0)}$. Albumin was removed from normal rat serum by chromatography with Affi-Gel blue, as described previously (20). More than $98 \%$ of the albumin was removed by this method, as assessed by immunodiffusion after the serum was concentrated (as previously described [20]) back to its original $T_{4}$ and free $T_{4}$ concentrations (the final volume was $\sim 70 \%$ of the starting volume). This reconcentrated serum was used in the experiments.

\section{Results}

In vivo kinetics studies were performed in six Nagase analbuminemic rats and in six control rats. Albumin was detectable by immunodiffusion in the serum of all of the analbuminemic rats, but its concentration was $<0.1 \%$ of normal in all cases. Serum $\mathrm{T}_{4}$ concentrations were similar in the analbuminemic rats $(4.1 \pm 0.8 \mu \mathrm{g} / \mathrm{dl}$; mean $\pm \mathrm{SD})$ and in the control rats $(3.9 \pm 1.3 \mu \mathrm{g} / \mathrm{dl})$, and the serum-free $\mathrm{T}_{4}$ fractions were similar in each group $(0.045 \pm 0.013$ vs. $0.045 \pm 0.019 \%)$. Serum prealbumin concentrations in the analbuminemic rats were $136 \pm 41 \%$ of the concentration in serum pooled from the control rats, thus accounting for the same serum $\mathrm{T}_{4}$ concentrations in the two groups of rats, despite the absence of albumin in one group. The $T_{3}$ concentration in serum pooled from the analbuminemic rats was $0.68 \mathrm{ng} / \mathrm{ml}$ and that in serum pooled from the control rats was $0.45 \mathrm{ng} / \mathrm{ml}$, consistent with a previous report (12) that serum $T_{3}$ concentrations are similar in analbuminemic and control rats. Although an assay for rat thyroid-stimulating hormone was not available, serum thyroidstimulating hormone concentrations in analbuminemic rats have previously been reported to be slightly above normal (12).

Analysis of the plasma disappearance curves of simultaneously injected ${ }^{131} \mathrm{I}$-albumin and ${ }^{125} \mathrm{I}_{-} \mathrm{T}_{4}$ (Fig. 1) showed that $\mathrm{T}_{4}$ flux from the extracellular compartment to the rapidly exchangeable intracellular compartment and $T_{4}$ pool size in the rapidly exchangeable intracellular compartment were similar

Table I. In Vivo $T_{4}$ Kinetics

\begin{tabular}{|c|c|c|c|c|c|c|c|}
\hline Controls & Plasma $T_{4}$ & $V_{E}$ & $K_{\mathrm{E}}$ & $V_{\mathrm{E}} \cdot K_{\mathrm{E}}$ & $T_{4}$ flux & $V_{1}$ & $Z_{1}$ \\
\hline & $\mu g / d l$ & $m l$ & $\min ^{-1}$ & $\mathrm{ml} / \mathrm{min}$ & $n g / \min$ & $m l$ & $\mu g$ \\
\hline 1 & 5.2 & 9.5 & 0.12 & 1.14 & 59 & 22.5 & 1.17 \\
\hline 2 & 5.0 & 7.4 & 0.16 & 1.19 & 53 & 27.0 & 1.35 \\
\hline 3 & 4.5 & 11.3 & 0.16 & 1.81 & 81 & 25.5 & 1.15 \\
\hline 4 & 2.6 & 9.9 & 0.16 & 1.59 & 41 & 29.7 & 0.77 \\
\hline 5 & 3.7 & 11.9 & 0.11 & 1.31 & 48 & 49.4 & 1.83 \\
\hline 6 & 2.1 & 11.2 & 0.17 & 1.91 & 40 & 49.0 & 1.03 \\
\hline Mean \pm SD & $3.9 \pm 1.3$ & $10.2 \pm 1.6$ & $0.15 \pm 0.03$ & $1.49 \pm 0.33$ & $54 \pm 15$ & $33.9 \pm 12.1$ & $1.22 \pm 0.36$ \\
\hline \multicolumn{8}{|l|}{ Analbuminemics } \\
\hline 7 & 3.4 & 10.5 & 0.10 & 1.05 & 36 & 26.9 & 0.91 \\
\hline 8 & 4.9 & 9.5 & 0.07 & 0.66 & 33 & 17.9 & 0.88 \\
\hline 9 & 3.2 & 11.5 & 0.11 & 1.27 & 41 & 25.1 & 0.80 \\
\hline 10 & 4.0 & 12.3 & 0.10 & 1.23 & 49 & 19.7 & 0.79 \\
\hline 11 & 3.9 & 12.4 & 0.12 & 1.49 & 58 & 31.9 & 1.24 \\
\hline 12 & 5.2 & 14.3 & 0.12 & 1.71 & 89 & 41.6 & 2.17 \\
\hline Mean \pm SD & $4.1 \pm 0.8$ & $11.8 \pm 1.7$ & $0.10 \pm 0.02$ & $1.24 \pm 0.36$ & $51 \pm 21$ & $27.2 \pm 8.7$ & $1.13 \pm 0.53$ \\
\hline
\end{tabular}

All volumes and pool sizes are adjusted to $300 \mathrm{~g}$ body weight. $V_{\mathrm{E}}$, early distribution volume of the extracellular compartment; $K_{\mathrm{E}}$, rate constant for transfer from the extracellular compartment into the rapidly exchangeable intracellular compartment; flux, rate of transfer from the extracellular compartment into the rapidly exchangeable intracellular compartment; $V_{I}$, distribution volume of the rapidly exchangeable intracellular compartment; $Z_{\mathrm{I}}$, pool size of $V_{\mathrm{I}}$. 


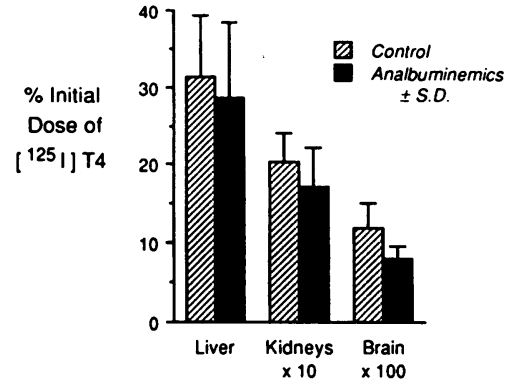

in the two groups of rats (Fig. 2 and Table I). Direct analysis of tissue samples obtained at $35 \mathrm{~min}$ after injection also showed similar intracellular contents of ${ }^{125} \mathrm{I}-\mathrm{T}_{4}$ in the two groups of rats (Fig. 3). The intracellular ${ }^{125} \mathrm{I}_{-} \mathrm{T}_{4}$ contents that we found in liver $(\sim 30 \%$ of the injected dose) and kidneys $(\sim 2 \%)$ at 35 min after injection are very similar to the corresponding values obtained by Hasen et al. (14) (26\% in liver and $2.4 \%$ in kidneys). The slight differences between the analbuminemic and control rats observed in Fig. 3 may be due to a slightly greater extracellular volume of distribution of $\mathrm{T}_{4}$ in the analbuminemic rats (Table I).

In vitro kinetics studies using the isolated perfused rat liver were also performed. Uptake by normal rat liver of $T_{4}$ in serum pooled from Nagase analbuminemic rats was similar to that of $\mathrm{T}_{4}$ in serum pooled from control rats (Table II). In addition, uptake by normal rat liver of $\mathrm{T}_{4}$ in pooled normal rat serum was similar to that of $\mathrm{T}_{4}$ in pooled normal rat serum from which $>98 \%$ of the albumin had been removed by chromatography with Affi-Gel blue (Table III).

\section{Discussion}

These data indicate that there is no special, substantive role for albumin in $T_{4}$ transport in the rat. In vivo kinetics studies revealed similar rates of flux of $T_{4}$ from the extracellular compartment into the rapidly exchangeable intracellular compartment in Nagase analbuminemic rats and in control rats. In addition, the size of the rapidly exchangeable intracellular pool of $\mathrm{T}_{4}$ was similar in the two groups of rats. In vitro kinetics studies revealed similar rates of uptake by normal rat liver of $\mathrm{T}_{4}$ in serum from Nagase analbuminemic rats and in serum from control rats. Furthermore, when albumin was removed from normal rat serum, hepatic $T_{4}$ uptake was unaffected. Albumin thus appears to be unnecessary to maintain a normal rate of transport of $\mathrm{T}_{4}$ from the extracellular compartment into the rapidly exchangeable intracellular compartment in the rat.

These findings are not readily compatible with the enhanced dissociation hypothesis, which states that a special cat-

Table II. Percent Uptake of $T_{4}$ from Serum by Perfused Normal Rat Liver

\begin{tabular}{ll}
\hline & $\begin{array}{c}\text { \% Uptake } \\
( \pm S D, n=3)\end{array}$ \\
\hline Control rat serum & $11.4 \pm 3.4 \%$ \\
Analbuminemic rat serum & $10.9 \pm 3.3 \%$ \\
\hline
\end{tabular}

Table III. Percent Uptake of $T_{4}$ from Serum by Perfused Normal Rat Liver

\begin{tabular}{lc}
\hline \multicolumn{1}{c}{ Bolus method* } & $\begin{array}{c}\% \text { uptake } \\
( \pm \mathrm{SD}, n=5)\end{array}$ \\
\hline $\begin{array}{l}\text { Normal rat serum } \\
\begin{array}{l}\text { Normal rat serum from which the albumin had been } \\
\text { removed by chromatography with Affi-Gel blue }\end{array}\end{array}$ & $15.2 \pm 2.5 \%$ \\
\hline
\end{tabular}

The percent free $\mathrm{T}_{4}$ in both sera was $0.048 \%$.

* Because of the small volume of albumin-free serum available for these studies, a bolus injection method (see Methods) was used for the studies shown here. The slightly greater hepatic uptakes of $T_{4}$ observed with this method, as compared with the method used to collect the data in Table II, may be due to some mixing of the injected bolus with the protein-free buffer of the perfusate.

alytic mechanism exists within tissues to selectively release hormones from certain proteins but not from others (7). When interpreted in light of this hypothesis, previously obtained data have indicated that this special mechanism must act on the albumin- $\mathrm{T}_{4}$ complex in the rat, but not on the prealbumin- $\mathrm{T}_{4}$ complex (5). ${ }^{3}$ If this hypothesis were true, analbuminemic rats would be expected to have greatly decreased rates of entry of $T_{4}$ into tissues ( $<1 \%$ of the observed hepatic uptake of $T_{4}$ is considered to proceed via the pool of free $T_{4}$ in this hypothesis, and none is considered to proceed via the pool of TBPAbound $\left.\mathrm{T}_{4}[5]\right)$. Our data indicate that they do not. In contrast, our findings are entirely compatible with the concept that the circulating free $T_{4}$ pool is the driving force for $T_{4}$ uptake by cells.

Previous tests of the enhanced dissociation hypothesis, in which experimental data were analyzed in terms of whether they were better predicted by this model or by a more traditional model of hormone transport, have been conducted (5-7). These tests, however, were all predicated on the assumption that tissue uptake rate constants for free hormones are uniformly very low $\left(\ll 1 \mathrm{~s}^{-1}\right)(3,4)$. In the absence of this assumption, both models examined would have fitted the data equally well $(3,4)$, and recent data indicate that this assumption is unlikely to be correct $(3,4,10,21)$. This study, therefore, is the first valid experimental test of the enhanced dissociation hypothesis.

Our present findings are also consistent with a previous study in which we documented normal $\mathrm{T}_{4}$ transport and disposal rates in subjects with familial dysalbuminemic hyperthyroxinemia (FDH) (16). A more recent study of $T_{4}$ kinetics in subjects with $\mathrm{FDH}$, however, found that $\mathrm{T}_{4}$ disposal rates in this syndrome were increased by $43 \%$ (22). The authors of that study concluded that $T_{4}$ bound to the abnormal albumin of FDH was therefore "more available to tissues" than $T_{4}$ bound to other plasma proteins. What those authors did not point out, however, was that the serum-free $T_{4}$ concentrations in

3. Although another $\mathrm{T}_{4}$-binding protein (in addition to albumin and TBPA) apparently exists in rat plasma (19), its affinity for $T_{4}$ appears to be very weak, such that it binds much less $T_{4}$ than does albumin (19). A catalytic mechanism acting on this protein, although not excluded by our present data, thus would not be expected to account for the observed rates of tissue uptake of $T_{4}$ from rat plasma. 
their subjects with FDH were $40 \%$ higher than those in their control subjects. Their data thus can be fully accounted for without postulating a special role for albumin in $T_{4}$ transport. The reason that the subjects with FDH in that study had serum free $\mathrm{T}_{4}$ concentrations that were $40 \%$ higher than those of the control subjects is at present unclear to us.

Several methodological aspects of our in vivo kinetics studies deserve comment. Although we detected no differences between the $T_{4}$ transport rates in Nagase analbuminemic rats and those in control rats, we cannot exclude the possibility that small differences in these rates really did exist, particularly in light of the large individual differences within each group (Table I). Nevertheless, our conclusion that the predominant mechanism of $\mathrm{T}_{4}$ uptake by tissues in the rat does not involve albumin seems firm and remains in contradistinction to the predictions of the enhanced dissociation hypothesis. Another methodological aspect of these studies that requires emphasis is the fact that some of the $T_{4}$ in the extraalbumin space (rapidly exchangeable intracellular compartment) at $35 \mathrm{~min}$ after injection may really be in interstitial fluid rather than intracellular. Although most of the $T_{4}$ in the rapidly equilibrating tissue pools (i.e., liver and kidneys) is intracellular (23), much of the $\mathrm{T}_{4}$ in many of the more slowly equilibrating tissue pools (e.g., skeletal muscle) appears to be in interstitial fluid, at least in the sheep (23). In the rat, a significant amount of injected $T_{4}$ - in the more slowly equilibrating pools by $35 \mathrm{~min}$ after injection (24) (a comparison of our data shown in Figs. 2 and 3 is also consistent with this). Our measured rates of $T_{4}$ transfer into the extraalbumin space thus may represent composite rates, which include direct transfer of $T_{4}$ from plasma to cells in the liver and transfer of $T_{4}$ from plasma to interstitial fluid in other tissues. Nevertheless, mechanisms of $T_{4}$ transport across capillaries (to interstitial fluid) are postulated to be the same as those operative within hepatic sinusoids in both the free hormone transport hypothesis and the enhanced dissociation hypothesis (7). Therefore, the significance of the similarity of our measured rates of $\mathrm{T}_{4}$ transport in Nagase analbuminemic rats and in control rats is independent of whether this transport occurs primarily from plasma to the liver or also to other tissues.

The question of whether tissue uptake of hormone occurs via the pool of free hormone or via the pool of protein-bound hormone has often been confused with the question of which fraction of hormone in plasma reflects the biological activity of that hormone. As we have previously pointed out, these are two independent questions (3). It can be shown mathematically that the free, rather than the protein-bound, $T_{4}$ concentration in plasma is expected to affect intracellular $T_{4}$ concentrations (in accord with the free hormone hypothesis), regardless of whether the tissue uptake mechanism for $T_{4}$ acts on the free pool or on the protein-bound pool $(3,21)$. We believe that most or all evidence obtained to date is also consistent with the hypothesis that tissue uptake of $\mathrm{T}_{4}$ occurs exclusively via the pool of free $T_{4}(3,4)$. Whether or not this turns out to be entirely correct, our data clearly indicate that albumin does not play a special, substantive role in $T_{4}$ transport in the rat.

\section{Acknowledgments}

We thank Marie Moeller for expert assistance with the animal surgery, Dr. Anders Carlström for help related to the electroimmunoassay for
TBPA, Dr. Sumi Nagase and Dr. J. Roy Chowdhury for providing the analbuminemic rats, and Dr. Richard A. Weisiger for helpful discussions.

This work was supported by grants HL-01546 (Clinical Investigator Award), DK-26743 (Liver Center), and HL-14237 (Arteriosclerosis Specialized Center of Research) from the National Institutes of Health, and by the Medical Research Service of the Veterans Administration.

\section{References}

1. Hillier, A. P. 1971. The mechanism of thyroxine transfer from plasma to tissue binding sites. J. Physiol. 217:635-639.

2. Pardridge, W. M. 1981. Transport of protein-bound hormones into tissues in vivo. Endocr. Rev. 2:103-123.

3. Mendel, C. M., R. R. Cavalieri, and R. A. Weisiger. 1988. Uptake of thyroxine by the perfused rat liver: implications for the free hormone hypothesis. Am. J. Physiol. 255:E110-E119.

4. Mendel, C. M., R. R. Cavalieri, and R. A. Weisiger. 1988. On plasma protein-mediated transport of steroid and thyroid hormones. Letter to the Editor. Am. J. Physiol. 255:E221-E224.

5. Pardridge, W. M., B. N. Premachandra, and G. Fierer. 1985. Transport of thyroxine bound to human prealbumin into rat liver. $\mathrm{Am}$. J. Physiol. 248:G545-G550.

6. Pardridge, W. M., and E. M. Landaw. 1984. Tracer kinetic model of blood-brain barrier transport of plasma protein-bound ligands: empiric testing of the free hormone hypothesis. J. Clin. Invest. 74:745-752.

7. Pardridge, W. M. 1987. Plasma protein-mediated transport of steroid and thyroid hormones. Am. J. Physiol. 252:E157-E164.

8. Cavalieri, R. R., J. N. Castle, and F. A. McMahon. 1984. Effects of dexamethasone on kinetics and distribution of triiodothyronine in the rat. Endocrinology. 114:215-221.

9. Tata, J. R. 1960. Biochemical applications of a newly discovered property of thyroxine. Ann. NY Acad. Sci. 86:469-483.

10. Mendel, C. M., R. A. Weisiger, A. L. Jones, and R. R. Cavalieri. 1987. Thyroid hormone-binding proteins in plasma facilitate uniform distribution of thyroxine within tissues: a perfused rat liver study. Endocrinology. 120:1742-1749.

11. Nagase, S., K. Shimamune, and S. Shumiya. 1979. Albumindeficient rat mutant. Science (Wash. DC). 205:590-591.

12. Takahashi, M., K. Wakabayashi, and S. Nagase. 1984. Hormone levels of anterior pituitary gland and serum in Nagase analbuminemia rats. Endocrinol. Jpn. 31:185-193.

13. Inoue, M. 1985. Metabolism and transport of amphipathic molecules in analbuminemic rats and human subjects. Hepatology (Baltimore). 5:892-898.

14. Hasen, J., G. Bernstein, E. Volpert, and J. H. Oppenheimer. 1968. Analysis of the interchange of thyroxine between plasma and liver and plasma and kidney in the intact rat. Endocrinology. 82:3746.

15. Oppenheimer, J. H., G. Bernstein, and J. Hasen. 1967. Estimation of rapidly exchangeable cellular thyroxine from the plasma disappearance curves of simultaneously administered thyroxine- ${ }^{131} I$ and albumin- ${ }^{125}$ I. J. Clin. Invest. 46:762-777.

16. Mendel, C. M., and R. R. Cavalieri. 1984. Thyroxine distribution and metabolism in familial dysalbuminemic hyperthyroxinemia. J. Clin. Endocrinol. \& Metab. 59:499-504.

17. Mendel, C. M., and R. R. Cavalieri. 1984. Red blood cell thyroxine in nonthyroid illness and in heparin-treated patients. J. Clin. Endocrinol. \& Metab. 58:1117-1124.

18. Laurell, C.-B. 1972. Electroimmunoassay. Scand. J. Clin. Lab. Invest. 29(Suppl. 124):21-37.

19. Larsson, M., T. Pettersson, and A. Carlström. 1985. Thyroid hormone binding in serum of 15 vertebrate species: isolation of thyroxine-binding globulin and prealbumin analogs. Gen. Comp. Endocrinol. $58: 360-375$. 
20. Mendel, C. M., P. H. Frost, and R. R. Cavalieri. 1986. Effect of free fatty acids on the concentration of free thyroxine in human serum: the role of albumin. J. Clin. Endocrinol. \& Metab. 63:1394-1399.

21. Mendel, C. M., R. A. Weisiger, and R. R. Cavalieri. 1988. Uptake of 3,5,3'-triiodothyronine by the perfused rat liver: return to the free hormone hypothesis. Endocrinology. 123:1817-1824.

22. Bianchi, R., G. Iervasi, A. Pilo, F. Vitek, M. Ferdeghini, F. Cazzuola, and G. Giraudi. 1987. Role of serum carrier proteins in the peripheral metabolism and tissue distribution of thyroid hormones in familial dysalbuminemic hyperthyroxinemia and congenital elevation of thyroxine-binding globulin. J. Clin. Invest. 80:522-534.

23. Irvine, C. H. G. 1974. Concentration of thyroxine in cellular and extracellular tissues of the sheep and the rate of equilibration of labeled thyroxine. Endocrinology. 94:1060-1071.

24. DiStefano, J. J. III, T. K. Malone, and M. Jang. 1982. Comprehensive kinetics of thyroxine distribution and metabolism in blood and tissue pools of the rat from only six blood samples: dominance of large, slowly exchanging tissue pools. Endocrinology. 111:108-117.

25. Sutherland, R. L., and M. R. Brandon. 1976. The thyroxinebinding properties of rat and rabbit serum proteins. Endocrinology. 98:91-98.

26. Esumi, H., S. Sato, M. Okui, T. Sugimura, and S. Nagase. 1979. Turnover of serum proteins in rats with analbuminemia. Biochem. Biophys. Res. Commun. 87:1191-1199. 